\title{
NOWHERE TO GO: PREDICAMENT OF A MOTHER IN BABURAO BAGUL'S “MOTHER”
}

\author{
Dr. Sangita Kongre, Dr. Karthik Panicker
}

\author{
Assistant Professor \\ Department of English \\ M.D. College \\ Parel, Mumbai-12 \\ Maharashtra \\ sangtiakongre@gmail.com \\ Assistant Professor \\ Department of English \\ J. M. Patel College \\ Bhandara-441904 \\ Maharashtra \\ karthikpanicker2025@gmail.com
}

\begin{abstract}
Dalit literature is an important body of work voicing the issues of the 'marginalized' sections of society. It highlights the subjugation and the social, political and economic exploitation of the Dalits. Baburao Bagul's story "Mother" poignantly depicts the pain and sufferings of a Dalit woman. Women hailing from Dalit society are the 'marginalized of the marginalized'. These women suffer at multiple levels. The present research paper tries to explore plight of a widow who is surrounded by all kinds of problems. The writer keeps the protagonist - the mother - nameless to suggest not only her insignificant existence but also the universal suffering of such women. A good part of her life is made hell by her TB ridden husband. After his death she is left to fend for herself and her son. But all her efforts of being a good mother are defeated. Ultimately, she finds herself torn between her personal happiness and the her responsibilities as a mother.
\end{abstract}

Keywords: Dalit-women, sufferings, personal happiness, and predicament

The widow is a figure whose very life is marked by a specific death. She is 'vidhva'-without husband-and consequently in need not only of public protection, but also of regulation, governance. (Tharu Susie, 1311)

The above quote very aptly describes the painful life of the protagonist - a dalit woman who is a widow and a mother to a son named Pandu. The term 'Dalit' was dominantly used during the British Raj. Arjun Dangle, in the 'Introduction' remarks: "Dalit is not a caste but a realization and is related to the experiences, joys and sorrows, and struggles of those in the lowest stratum of society" (Poisoned Bread, iii). There are many writers, themselves hailing from the marginalized sections of the society, who have voiced the sufferings and various issues of Dalits through their literature. Writers like Anna Bhau Sathe, Shankarrao Kharat, Namdeo Dhasal, Urmila Pawar, Umakant Randir, Daya Pawar, Yogendra Meshram, Meena Kandasamy, Bama, Anant Rao Akela, Anita Bharti and Shantabai Krishnabai Kamble - to name a few - have penned the pains and sufferings of this section of the society.

Sharankumar Limbale writes, "Dalit literature is precisely that literature which artistically portrays the sorrows, tribulations, slavery, degradation, ridicule and poverty endured by Dalits. This literature is but a lofty image of grief." (Prasad, 178).

In his essay, "What is Dalit Literature?" Sharatchandra Muktibodh defines it as follows: Dalit Literature is the literature produced by the Dalit consciousness .... The nature of this literature consists in a rebellion against the suppression and humiliation suffered by the Dalits - in the past and even at present - in the framework of the Varna system." (Poisoned Bread, 270)

The works of these writers have contributed a lot in bringing about a change in the changing lives of 'marginalized' strata of society. These writings have played an important role in mobilizing the community politically and socially. Among these is Baburao Bagul who writes an "... extremely frank analysis of society, religion and literature and throw down a revolutionary gauntlet..." (Arjun Dangle, XIII). Baburao Bagul's collection of short stories Jevha Mi Jaat Chorli Hoti (When I had Concealed My Caste) took the entire Marathi literary world by storm.

The short story "Mother" by Baburao Bagul is poignant tale of a dalit woman who is not only a victim of domestic violence but also the impossible situation created by the society. She is beautiful and is married off at a young age. She almost becomes a victim of her brother-in-law's lust in the village. When her husband comes 


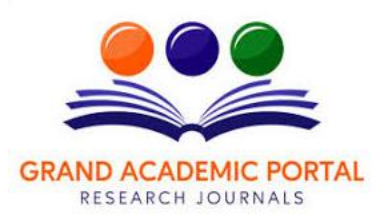

GAP BODHI TARU

A GLOBAL JOURNAL OF HUMANITIES

( ISSN - 2581-5857)

Impact Factor: SJIF - 5.171, IIFS - 5.125

Globally peer-reviewed and open access journal.

to know of this, he 'almost killed his bother with an axe'. (214) They leave the village and come to the metropolis in search of a livelihood. The have a child, Pandu. In course of time, her husband gets afflicted by tuberculosis. As a result, he is not able to go to work. Things start getting difficult for them. Her husband needed 'medicines, milk and fruit' (214) and needs of infant Pandu had also to be catered to. To keep the kitchen fires going, she starts working 'at the construction sites, hauling bricks and cement'. (214) But this only increases her troubles. On her return from work, she has to face the 'dark suspicion' (214) of her husband. 'She was beautiful, desirable' (214) and therefore he believed that she sold her beauty for a price. Therefore, on her return from work, she had to undergo the 'degrading act' (214) of being stripped and examined by him: "He would strip her and examine her feet, scrutinize her lips and cheeks. His eyes would constantly seek proof, proof that she was indeed an adulteress." (214) He would search her for any money she might have earned selling her beauty. He calls her a 'slut'. With every passing day, his suspicion only grows. He assaults her physically on a daily basis with a purpose of destroying her beauty. His blows are all aimed at damaging her face, nose, head and eyes. He even blames her for all the problems - 'his disease, his failing strength and his joblessness' (214). All this physical and mental torture makes her life hell. She knows no happiness. Despite all this, she continues to take care of him. Looking at the difficulties they are facing, she even suggests to her husband that they should go back to their village. She tells him: "The men here harass me all the time and so do you. The village air will do you good." (214) But he refuses to go back as it means living with the brother whom he had tried to kill.

As her husband's condition deteriorates, she is subjected to more severe tortures. His suspicion grows. He desires for her body more than ever before. His accusations about her character became intolerable. She was in for the shock of her life when one night she wakes up from deep sleep to realize that she had been stripped off all her clothes and her husband heating up iron tongs to brand her body with the hot iron tongs. After this incident, she loses all her emotional attachment and regard for him. No that she loved him. But she did care for him as a wife. But this incident changes all that. Now she wishes for his death.

After her husband's death, life becomes even more difficult for her. She is desired by Men. There are attempts to molest and rape her. And she has to face the slander of their women. Her only goal now was to raise her son, Pandu. He becomes the sole purpose of her life. In the meanwhile, her longing for personal happiness makes her enter into a 'relationship' with an overseer. All kinds of stories about her get created and spread. These stories reach Pandu also. One day when a poem regarding a mother is taught in the class, Pandu likes it very much. He thinks about the love and greatness of his own mother. But his joy is short-lived when his class-mates start saying all kinds of things about his mother. There is a fight among the children and all the students gangup against the hapless Pandu. Beaten, and with his spirits dampened, he reaches home only to find that his mother has not yet come back from work. He looks for food, but there is nothing for him to eat. By the time she reaches home, the neighbors are ready with their set of abuses for her. She realizes that since the coming of the overseer in her life, she had not been able to care for Pandu. The loneliness of ten years had made her vulnerable. The overseer had come to fill her loneliness. For the first time she realized that her love for the overseer had been greater than the love for Pandu. She could not hug Pandu as earlier.

Pandu also felt that his mother had changed. She could see the same 'dark suspicion' of her husband in the eyes of Pandu. Even as she was persuading him to wear the new clothes, Pandu vent out his disgust at her - "Whore! I spit on your clothes" (217) - and ran out of the house. This came as a shocker for her. Ten years of widowhood and single parenting seemed to come to naught. She started cursing her fate. Pandu's words had hurt her more than her husband's. She thinks that the past is re-visiting her: "Was it for this that God sent to me? You've all tortured me - you, your father, the men in this street - also the women. For you, I waded through hell" (217).

She re-lives the period immediately after the death of her husband. She had offers from many men, but she refused all of them. She had turned down all the offers for the sake of Pandu, her child. And now that very child had called her a 'whore'. Even as she is thinking about all this, she hears a knock. She anticipates Pandu's return. But it is the overseer. He takes her in his arms. Even as she responds to his hug and her uncontrollable desire, she is not able to hear the faint "Mother!" cry of Pandu. Pandu had seen her in the tight embrace of the overseer. He rushes out of the house. She tries to follow him, but the overseer pulls her back into the room. She tried to free herself from the 'bear-like hug of the overseer' (218), but in vain. She felt like a 'person stuck fast in a quagmire' (218). Pandu had been the only goal and hope of her life. But Pandu's running away from her meant the collapse of her world. She finds herself at the new crossroads of her life.

To conclude the story raises some very pertinent questions about the status of women in a traditional society. A woman's role is defined. Her life is dictated by the norms decided by the society. Even today, it is very difficult for a young widow to decide on the course of her life. The protagonist of the story is all the more disadvantaged and challenged as she comes from the marginalized section of the society. She is a 'mother' and therefore, her attempts at personal happiness, in a traditional society, would always be questioned. She is traumatized by her neighbours - men and women alike. They see her as a transgressing widow, someone who flouts the sanctity of widowhood. With no support from any quarters, she is left to fend for herself. She finds herself torn between her own small personal happiness and the responsibilities of motherhood. Her condition reminds one of Simone de Beauvoir's remarks in her Introduction to the Second Sex about the condition of a woman: "The drama of woman lies in this conflict between the fundamental aspirations of every subject (ego) 


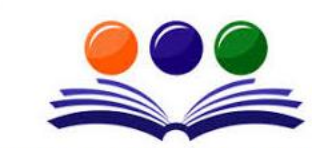

GRAND ACADEMIC PORTAL RESEARCH JOURNALS

- who always regards the self as the essential and the compulsions of a situation in which she is the inessential. How can a human being in woman's situation attain fulfillment? What roads are open to her? Which are blocked?" (Beauvoir, xxxv)

\section{REFERENCES}

Primary Source:

[1] Dangle, Arjun (Ed.) Poisoned Bread. New Delhi: Orient Black Swan. 2011. Print.

\section{Secondary Sources:}

[1] Patil, Smita (2008). Dalit Assertion in Society, Literature \& History. New Delhi: Manohar Publications.

[2] Pawar Urmila (2008). The Weave of My Life: A Dalit Woman's Memoirs. Tran. By Maya Pandit, Kolkata: STREE.

[3] Shah, Ghanshyam (2001). Dalit Identity and Politics. New Delhi: Sage Publications

[4] Tharu, Susie. "The Impossible Subject: Caste and the Gendered Body." Economic and Political Weekly, vol. 31, no. 22, Economic and Political Weekly, 1996, pp. 1311-15, http://www.jstor.org/stable/4404206.

[5] Zelliot Eleanor (2005). From Untouchables to Dalit: Essays on the Ambedkar Movement. New Delhi: Manohar Publications

[6] http://www.indianruminations.com/contents/research-article-contents/dalit-feminism-andbaburaobaguls-short-story-mother-swayamdipta-das-kolkata/13-10-2017 11:57:02/Web.

[7] Prasad, Amar, Nath and Gaijan, M. B., (Ed). (2007) Dalit Literature: A Critical Exploration. New Delhi: Sarup \& Sons. Print.

[8] Beauvoir, Simone de (1989). The Second Sex. Translated and Edited by H. M. Parshley. New York: Vintage Books. 